\title{
Macroeconomic Factors and Renewable Energy Consumption in ASEAN Countries: A Dynamic Heterogeneous Panel Approach
}

Jain Yassin

To Link this Article: http://dx.doi.org/10.6007/IJARBSS/v11-i1/9001

DOI:10.6007/IJARBSS/v11-i1/9001

Received: 04 December 2020, Revised: 07 January 2021, Accepted: 16 January 2021

Published Online: 24 January 2021

In-Text Citation: (Yassin, 2021)

To Cite this Article: Yassin, J. (2021). Macroeconomic Factors and Renewable Energy Consumption in ASEAN Countries: A Dynamic Heterogeneous Panel Approach. International Journal of Academic Research in Business and Social Sciences, 11(1), 800-813.

\section{Copyright: @ 2021 The Author(s)}

Published by Human Resource Management Academic Research Society (www.hrmars.com)

This article is published under the Creative Commons Attribution (CC BY 4.0) license. Anyone may reproduce, distribute, translate and create derivative works of this article (for both commercial and non-commercial purposes), subject to full attribution to the original publication and authors. The full terms of this license may be seen at: http://creativecommons.org/licences/by/4.0/legalcode

Vol. 11, No. 1, 2021, Pg. 800 - 813

Full Terms \& Conditions of access and use can be found at http://hrmars.com/index.php/pages/detail/publication-ethics 


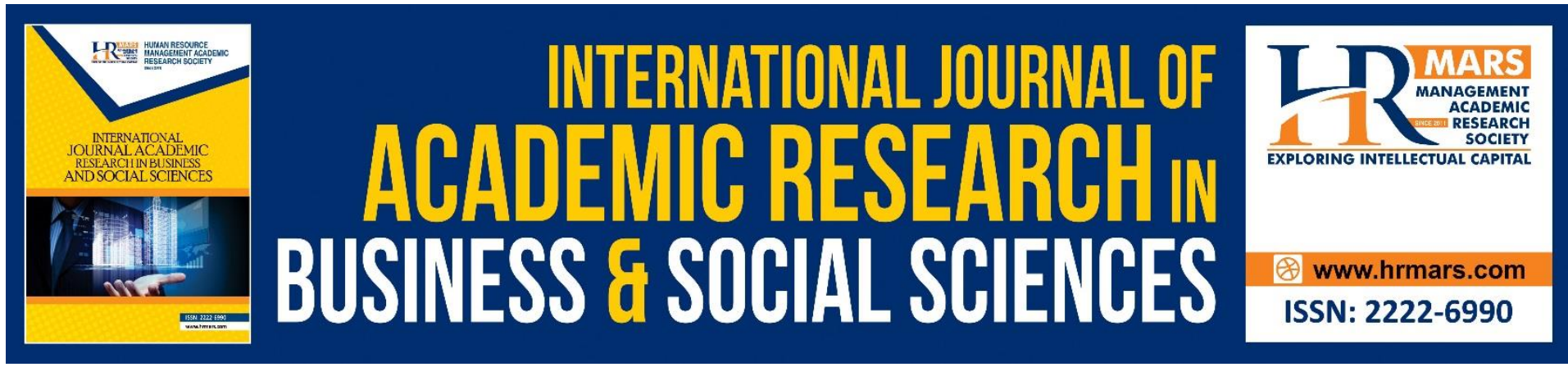

\title{
Macroeconomic Factors and Renewable Energy Consumption in ASEAN Countries: A Dynamic Heterogeneous Panel Approach
}

\author{
Jain Yassin \\ Faculty Business and Management, Universiti Teknologi MARA (UiTM), Kota Kinabalu, Sabah \\ Malaysia. \\ Email: jainyassin@uitm.edu.my
}

\begin{abstract}
This paper investigates the effects of macroeconomics factors on renewable energy consumption in ASEAN countries throughout 1990 - 2015. Compared to the previous studies, this study employed the newly developed Dynamic Common Correlated Effects to measure the cross-sectional dependence and heterogeneity among cross-sectional in a dynamic panel setting. The result revealed that the GDP and labor force is positively influenced by renewable energy consumption. On the other hand, foreign direct investment, trade openness, urbanization, and inflation rate are negatively related to renewable energy consumption. These findings have important implications for several policies to ensure a smooth movement to a low-carbon economy and encourage higher use of renewable energy.
\end{abstract}

Keywords: Macroeconomics Factors, Renewable Energy Consumption, Asean Countries, Dynamic Common Correlated Effects, Low-Carbon Economy.

\section{Introduction}

Energy is the major factor in supporting all aspects of social and economic. Globally, fossil fuel is a major source of energy since the 1900s. However, fossil fuel was responsible for several problems that countries face today. First, the rise of annual emissions such as release carbon dioxide, sulfur dioxide, nitrogen dioxide, and carbon monoxide which contribute approximately two-thirds of annual global greenhouse emissions (IRENA, 2019). Second, the cost increase in energy prices due to the threat of resource depletion.

In recent years, there has been increasing motivation for creating a low carbon economy realizing the Sustainable Development Goals (SGDs). The goals established by the United Nations provide a solid and clear benchmark to create a better world and environment for everyone. One of the highlighted frameworks is the progression of a low-carbon economy by putting renewable into the system for power generation. SDG 7 goals encompass three key targets. First, to provide an affordable, reliable, and availability of energy. Second, to increase the supply and consumption of renewable energy. Third, to improve energy efficiency globally.

The transition from conventional sources of energy consumption such as fossil fuel to renewable sources for energy also alarming as to overcome the future impact of energy 
(Danish et al. 2017). The Association of Southeast Asian Nations (ASEAN) has experienced expeditious paced of economic development rapid populations and urbanization. Moreover, the region is projected to become the fourth-largest economy in the world by 2030 (ADBI, 2017). ASEAN economic growth in line with its energy consumption. Statistically shows that energy consumption among ASEAN countries nearly doubled between 1995 and 2015 and is anticipated to rise by an average of 4.7 percent per year in 2035 (IRENA, 2018). This without a doubt has fuelled economic growth and improve the living standards in ASEAN.

Figure 1, shows the trends of consumption for renewable energy for nine ASEAN countries. According to data for renewable energy consumption in World Bank (2020), a decreasing trend of renewable energy consumption recorded. For example, comparing 1990 and 2015, Indonesia renewable energy consumption dropped from 58.6\% to $36.9 \%$, Malaysia dropped from $11.9 \%$ to $5.19 \%$, Philippine dropped from $50.9 \%$ to 27.5 , Thailand dropped from $33.6 \%$ to $22.8 \%$, Vietnam dropped from $76.1 \%$ to $34.9 \%$, Myanmar dropped from 90.9 $\%$ to $61.52 \%$, Laos dropped from $88.4 \%$ to $59.3 \%$, and Cambodia also dropped from $81 \%$ to $64.9 \%$.

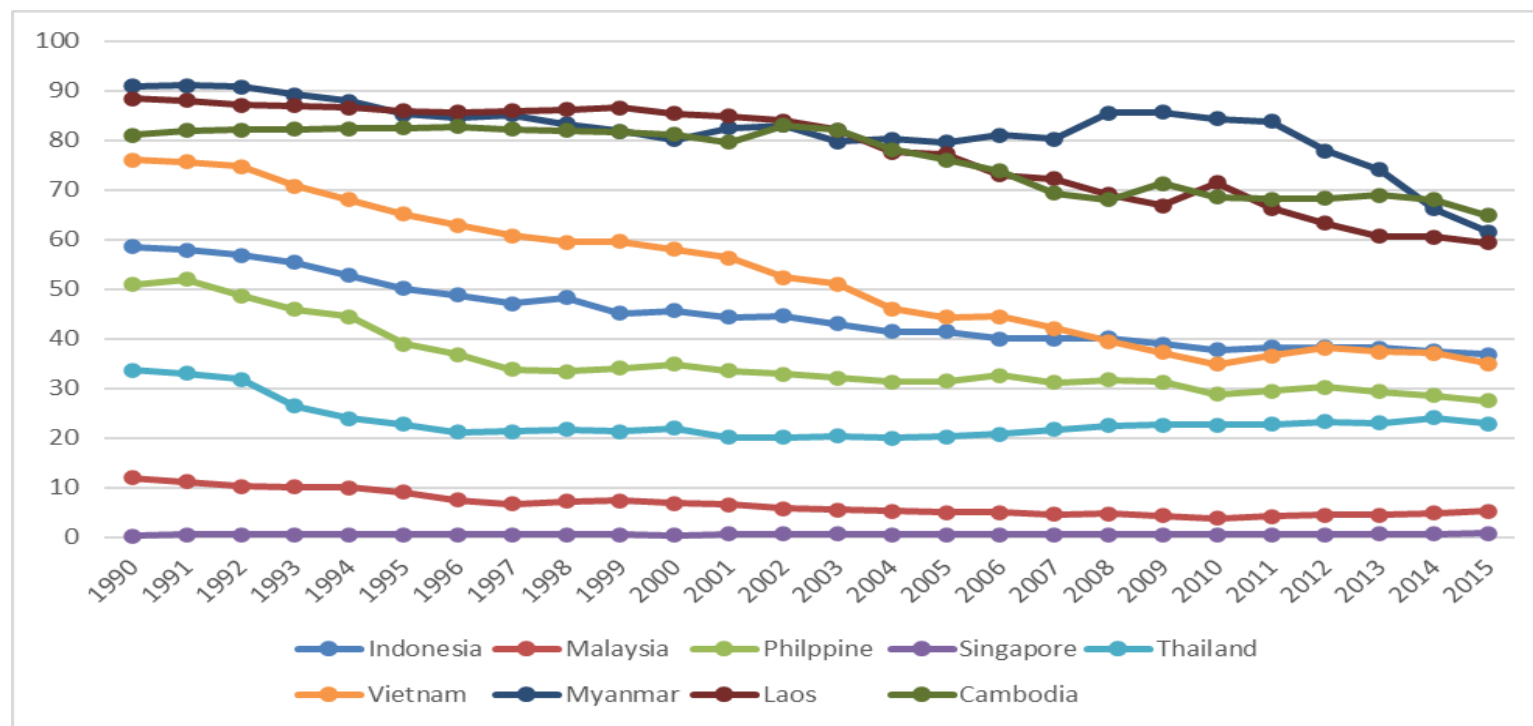

Figure 1: The trend of renewable energy consumption as \% of GDP for ASEAN countries (World Development Indicator, $2020^{1}$ )

Due to that, ASEAN agreed to set a target of 23 percent of its energy from renewable energy by 2025. Each ASEAN countries also committed to reducing its fossil-fuelled power and increase renewable energy as summarized in Table 1 . These policy goals reflect the concerns regarding conventional sources of energy consumption as well as environmental impacts.

\footnotetext{
${ }^{1}$ The ASEAN figure does not include Brunei Darussalam due to the non-availability of data.
} 
Table 1: ASEAN countries policies promoting renewable energy development

\begin{tabular}{|c|c|}
\hline Country & Policy \\
\hline Malaysia & $\begin{array}{l}\text { National Renewable Energy Policy, Action Plan 2011, and 11th Malaysia Plan } \\
2016-2020 \\
\text { - increase the electricity generation capacity through renewable sources } \\
\text { including biomass, biogas, solar PV, and mini-hydro are targeted to reach } \\
7.8 \% \text { of total installed capacity by } 2020 \text {. }\end{array}$ \\
\hline Indonesia & $\begin{array}{l}\text { National Energy Policy (2004) } \\
\text { - increase their renewable energy to } 31 \% \text { in } 2030 \\
\text { Green Energy Policy (2004) } \\
\text { - secure sufficient supply for the future generation }\end{array}$ \\
\hline Cambodia & $\begin{array}{l}\text { The Rural Electrification by Renewable Energy Policy (2006) } \\
\text { - encourage using renewable energy technologies in the rural area } \\
\text { Environment and Natural Resource Code } \\
\text { - support and promotion of sustainable energy projects }\end{array}$ \\
\hline Philippines & $\begin{array}{l}\text { Renewable Energy Act (2008) } \\
\text { - Fasten the search and establish renewable energy resources and reduce the } \\
\text { country's dependence on fossil fuels to minimize exposure to price } \\
\text { fluctuations in international markets }\end{array}$ \\
\hline Singapore & $\begin{array}{l}\text { National Energy Efficiency Committee (2001) } \\
\text { - Promote energy conservation and renewable energy; promote test- } \\
\text { bedding of pioneering energy technologies and commercialization of } \\
\text { energy technologies }\end{array}$ \\
\hline Vietnam & $\begin{array}{l}\text { Renewable Energy Development Strategy } 2016-2030 \\
\text { - expanding the scale and increasing the proportion of renewable energy } \\
\text { sources }\end{array}$ \\
\hline Lao PDR & $\begin{array}{l}\text { Renewable Energy Development Strategy (REDS) (2011) } \\
\text { - increase the share of renewable energies to } 30 \text { percent of the total energy } \\
\text { consumption by } 2025\end{array}$ \\
\hline Myanmar & $\begin{array}{l}\text { National Energy Policy } \\
\text { - Implement programs on a wider scale, utilizing renewable energy } \\
\text { resources such as wind, solar, hydropower, geothermal, and bioenergy for } \\
\text { sustainable energy development in Myanmar }\end{array}$ \\
\hline Thailand & $\begin{array}{l}\text { Energy Industry Act and Energy Conservation Promotion Act (2007) } \\
\text { - promote the use of renewable energy sources }\end{array}$ \\
\hline
\end{tabular}

Sources: Heng (2018), IRENA (2019), Rosellon (2017), Pillai (2014), ADB (2015).

The study on the macroeconomic factors and renewable consumption for ASEAN countries warrant an investigation for two reasons. First, KPMG REPORT (2019) stated that approximately 70 million people in ASEAN countries without access to reliable electricity, the potential for renewable energy is huge in those markets. Second, despite ASEAN's commitment to increasing its renewable energy consumption, nonetheless, the down-sloping 
trend of the consumption of renewable energy in ASEAN countries somewhat alarming and moving in the opposite direction from achieving the SDG objective. On that account, this study intends to investigate the effect of the macroeconomic factors on renewable energy consumption in ASEAN countries.

The remaining of this study is organized as follows. First, in section 2, several related literature on the determinants of renewable energy consumption discussed. After that, the model construction, data, and the estimator highlighted in sections 3 and 4 . Finally, the results estimated will be discussed in Section 5 and conclude in section 6 .

\section{Literature Review}

The existing literature widely used GDP per capita as an indicator of economic development. The association between renewable energy consumption and economic growth generally in the context of the EKC hypothesis. For instance, Bilgili and Ozturk (2015) tested the EKC hypothesis the OECD countries for the period 1977 to 2010 revealed that renewable energy consumption yields a positive influence GDP per capita and GDP per capita squared. This finding is consistent with Zhao and Luo (2017); China and Singh et al., (2019) for 20 developed and developing countries. In contrast, Cadoret and Padovano (2016) show that an increase in GDP will reduce renewable energy consumption in EU countries which also supported by Akar (2016) in Balkan countries.

Aside from only concentrated on economic growth proxied by GDP, numerous researchers also investigated several factors affecting renewable energy consumption for different countries using different econometric techniques. In addition to GDP, previous studies concentrated on macroeconomic variables such as foreign direct investment (FDI), trade openness, oil price, urban population, labor force, and Inflation.

In terms of individual countries, Lau et al. (2018) employed the autoregressive distributed lag (ARDL) bounds testing cointegration approach to examine the factors affecting renewable consumption in Malaysia for the period 1980 to 2015. This study revealed GDP and FDI significantly raise renewable energy consumption, while trade openness is found to have a negative impact on renewable energy consumption. A prior study by Lin et al. (2016) utilizing the Johansen cointegration technique and vector error correction in China for the years 19802011 also indicates that economic growth proxied by GDP tends to increase the renewable energy consumption, nevertheless, the foreign direct investment and trade openness reduce the consumption on renewable energy. Malik et al. (2014) examine the macroeconomics factors that influence renewable energy in Pakistan from 1975 to 2012. This study adopted the granger causality and indicate that GDP, population growth, urbanization, and inflation rate exerts positive effects on renewable energy in Pakistan. A more recent study, Zhao et al. (2020) also investigate the determinants of renewable energy demand in China from 1980 to 2016. This study uses the fully modified ordinary least squares (FMOLS) technique and revealed that economic growth positively impacts renewable energy, while, trade openness is a negative impact on renewable energy.

In a panel study, Omri and Nguyen (2014) adopting the dynamic system-GMM panel model for 64 countries over the period 1990-2011. This study found that the main determinants of renewable energy consumption are carbon emissions and trade openness. On the other hand, Oil prices have a minimal effect but a negative impact on renewable energy consumption. Ergun et al. (2019) examined 21 African countries in the period of 19902013 using the random-effects generalized least squares regression and found that foreign direct investment is positively related to renewable energy consumption while the gross 
domestic product found to be negatively influenced the renewable energy consumption. On the other hand, Chen (2018) highlighted the roles of import and export toward energy consumption in China. Using the dynamic system-GMM panel method, his study concluded that the increase in export will increase the consumption of renewable energy in China.

In the context of ASEAN, Kumaran et al. (2020) examine the determinants of renewable energy consumption in selected ASEAN countries from 1990 to 2016 using FMOLS and DOLS analyses. Based on the study, urbanization and quality of government have a positive impact on renewable energy. Meanwhile, GDP and trade openness found to negatively related to renewable energy consumption.

From the review works of literature, the effect of each determinant produces mixed results. The present study is different in previous literature based on the following. First, although different econometric models adopted, the newly developed Dynamic Common Correlated Estimators have not been used in previous studies.

\section{Model Construction and Data}

To assess the effect of macroeconomics factors on renewable energy consumption for ASEAN countries, this study developed the econometric model as follows:

$$
R E C=f(G D P P C, F D I, L F, T O, U R B, I N F)
$$

Equation (1) indicates a renewable energy consumption (REC) which depending on macroeconomic factors, namely, GDP per capita (GDPPC), foreign direct investment (FDI), labor force participation (LF), trade openness (TO), urban population (URB), and inflation rate (INF). Next, taking natural logarithms of equation (1) and transform it into a linear specification in a dynamic panel as follow.

InREC $_{i t}=\beta_{0}$ InREC $_{i t-1}+\beta_{1} \ln G D P P C+\beta_{2} \operatorname{InFDI}_{i t}+\beta_{3} \operatorname{lnLF}_{i t}+\beta_{4} \operatorname{lnTO}_{i t}+\beta_{4} \ln U R B_{i t}+\beta_{4} \operatorname{lnINF}_{i t}$ $+\lambda_{\mathrm{i}} \mathrm{f}_{\mathrm{t}}+\varepsilon_{\mathrm{it}}$

(2)

Where the $i=1 \ldots \mathrm{N}$, and $\mathrm{t}=1 \ldots \mathrm{T}$ refers to the cross-section and times of the panel respectively. To estimate the dynamic effects and heterogeneity across ASEAN countries, the above equations include a pervious value REC and vector of slope coefficent as heterogeneous across $\mathrm{N}$. Thus, the error term $\left(e_{i t}\right)$ capturing the unobserved country-specific effect $\left(f_{t}\right)$ that includes the individual heterogeneity factor loadings $\left(\lambda_{i}\right)$ and the remaining disturbance term $\left(\varepsilon_{i t}\right)$.

GDPPC is expected to have a positive association with REC. Higher economic growth accelerates the spread of renewable energy technologies (Frondel et al., 2010). Meanwhile, FDI and TO are expected to have a positive sign. According to Kumaran et al. (2020), most ASEAN countries investors and trading partners are from developed countries that owned and advance in cleaner technology. Next, Hassine and Harrathi (2017) stated an increase in the labor force has motivated more investment in renewable energy. The URB also expected to have a positive sign as according to ecological modernization theory, high urbanization may motivate society to be more aware of protecting the environment (Yassin \& Aralas, 2019). Lastly, the inflation rate which generally used to measure changes in the cost of living expected to have a negative sign as the rising interest rate can increase the cost of renewable energy which reduces the demand for renewable energy (Schmidt et al., 2019).

The data set used in this study is annual frequency over the period 1990 to 2015 in ASEAN countries and taken from the World Development Indicator (2020). ASEAN countries included Cambodia, Indonesia, Laos, Malaysia, Myanmar, the Philippines, Singapore, 
Thailand, and Vietnam. The chosen group of countries is selected due to the availability of data on renewable energy consumption (REC) which is the dependent variable. The description for each variable used is given in Table 3.

Table 2: Description and Unit of the Data

\begin{tabular}{|c|c|c|}
\hline Variable & Data Description & Unit of Measurement \\
\hline REC & $\begin{array}{l}\text { The percent share of renewable energy in } \\
\text { total final energy consumption }\end{array}$ & $\begin{array}{l}\text { measured in million tonnes } \\
\text { of oil equivalent (Mtoe) }\end{array}$ \\
\hline $\begin{array}{l}\text { GDPP } \\
\text { C }\end{array}$ & $\begin{array}{l}\text { Monetary value of all finished product } \\
\text { goods and services made within a country } \\
\text { at a specific period. }\end{array}$ & $\begin{array}{l}\text { Data in constant } 2010 \text { U.S. } \\
\text { dollars }\end{array}$ \\
\hline FDI & $\begin{array}{l}\text { Direct investment equity flows in the } \\
\text { reporting economy. }\end{array}$ & Data in current U.S. dollars. \\
\hline URB & $\begin{array}{l}\text { People living in urban areas as defined by } \\
\text { national statistical offices. }\end{array}$ & $\begin{array}{l}\text { Ratios of urban to the total } \\
\text { population }\end{array}$ \\
\hline $\mathrm{LF}$ & $\begin{array}{l}\text { The supply of labor available for producing } \\
\text { goods and services in an economy. }\end{array}$ & $\begin{array}{l}\text { Total people ages } 15 \text { and } \\
\text { older who currently } \\
\text { employ or unemployed } \\
\text { during a specified period }\end{array}$ \\
\hline TO & $\begin{array}{l}\text { Trade is the sum of exports and imports of } \\
\text { goods and services measured as a share of } \\
\text { gross domestic product. }\end{array}$ & Data in current U.S. dollars. \\
\hline INF & $\begin{array}{l}\text { Inflation as measured by the consumer } \\
\text { price index reflects the annual percentage } \\
\text { change in the cost to the average consumer } \\
\text { of acquiring a basket of goods and services. }\end{array}$ & $\begin{array}{l}\text { Based on the Consumer } \\
\text { Price Index (CPI) }\end{array}$ \\
\hline
\end{tabular}

\section{Dynamic Common Correlated Effects (DCCE)}

This study will utilize the newly developed Dynamic Common Correlated Effects (DCCE) estimator which considers heterogeneous coefficients as developed by Chudik and Pesaran (2015). The motivation behind this estimator selection due to the heterogeneity that may exist among ASEAN countries. This estimator provide more clearer pictures with the existence of unknown types of error cross-section dependence due to common stock and interdependencies, heterogeneity among the sample, and endogeneity from dynamic panel setting. To make is short, lets the model simplify as follow:

$$
y_{i t}=\alpha_{i}+\lambda_{i} y_{i t-1}+\beta_{i} x_{i t}+\sum_{\iota=0}^{p T} \delta_{i t \bar{z}_{t-1}}^{\prime}+\varepsilon_{i t}
$$

Where,

$\bar{z}_{t}=\left(\bar{y}_{t}, \bar{y}_{t-1}, \bar{x}_{t}\right)$

$p T-$ The number of lags $(p T=\sqrt[3]{T})$

$\lambda_{i}-$ individual heterogeneity factor loading

$\beta_{i}$-the heterogeneous coefficient and randomly distribute around common mean

$\beta_{i}=\beta+v_{i}, v_{i} \sim I I D\left(0, \Omega_{V}\right)$

From equation $3, \lambda_{i}$ and $\beta_{i}$ are stacked into $\pi_{i}=\left(\lambda_{i t}, \beta_{i}\right)$. The mean group coefficient estimates as in equation 4: 


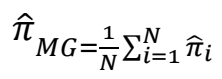

Where $\hat{\pi}_{i}$ and $\hat{\pi}_{M G}$ are consistently estimated with convergence rate $\sqrt{N}$ if $(N, T, p T) \Rightarrow \infty$. The asymptotic variances can be consistently under the full rank of factor loading estimation by:

$$
\operatorname{Var}\left(T_{M G}\right)=N^{-1} \sum_{\pi}^{\wedge}=\frac{1}{N(N-1)} \sum_{i=1}^{N}\left(\hat{\pi}_{i}-\hat{\pi}_{M G}\right)\left(\hat{\pi}_{i}-\hat{\pi}_{M G}\right)^{\prime}
$$

The mean group estimates have the following asymptotic distribution:

$$
\sqrt{N}\left(\hat{\pi}_{M G}-\pi\right) \stackrel{d}{\rightarrow} N\left(0, \sum_{M G}\right)
$$

In addition, the dynamic common correlated effect allows for Pooled Mean Group (PMG) estimations within the dynamic setting. According to Pesaran et al. (1999) the PMG estimators are the intermediary between heterogeneous and homogenous coefficients. This estimator will control the dependency by adding a cross-sectional means and lags. Furthermore, this estimator able to calibrate a small sample times series bias using the jackknife correction method and the recursive mean adjustment proposed by Chudik and Pesaran (2015). The mean group estimate of the Jackknife bias-corrected DCCE estimators as follow:

Where,

$$
\hat{\pi}_{M G}=2 \hat{\pi}_{M G}-\frac{1}{2}\left(\hat{\pi}_{M G(a)}+\hat{\pi}_{M G(b)}\right)
$$

$\hat{\pi}_{M G(a)}$-Mean group estimate of the first half $\left.\left(\mathrm{t}=\frac{T}{2}+1, \ldots, T\right)\right)$

$\hat{\pi}_{M G(b)}$ - Mean group estimate of the second half $\left(\mathrm{t}=1 \ldots \frac{T}{2}\right)$

The Jackknife derived by first, estimating the first half of the existing time period $\left(\hat{\pi}_{M G(a)}\right)$ and the second half $\left(\hat{\pi}_{M G(b)}\right)$ separately then taking the average value of the Mean Group Dynamic Common Correlated Effect. Interestingly, the estimation also generates crosssectional dependence (CD) test. The employment of the Dynamic Common Correlated Effects (DCCE) model due to several reasons.

\section{Result}

The estimation starts with testing the serial correlation using the Wooldridge test and the presence of heteroscedasticity using the modified Wald test as reported in Table 3 . The results conclude there is a cross-sectional dependence among ASEAN countries. Besides, the error structure is assumed to be heteroskedastic and auto-correlated due to possibly correlated between the groups (Hoechle, 2007).

Table 3: Diagnostic Tests

\begin{tabular}{|l|c|}
\hline \multicolumn{2}{|c|}{ Model 1 } \\
\hline Wooldridge test & $4677.64 * * *$ \\
\hline Modified Wald & $1770.24 * * *$ \\
\hline
\end{tabular}

Note: $\left({ }^{*}\right)$ significant at the 10 percent level, $\left({ }^{* *}\right)$ significant at the 5 percent level, and $\left({ }^{* * *}\right)$ significant at the 1

Table 4 shows the results of the first-generation panel unit-roots of Levin et al. (2002) and Im et al. (2003). The panel unit root is tested both at level and first difference. Both tests show mixed results at level. The Levin et al. (2002) test without trend found that InGDPPC, 
InLF, and InINF are stationary while other variables found to be not stationary at level. When trends included, InREC, InGDPPC, InTO, and InURB found to stationary at level. Meanwhile, InFDI, InLF, and InINF found to be not stationary at level. On the other hand, the Im et al. (2003) test without trend shows that only InREC and InURB found to not stationary at level, while other variables found to be stationary. When trends included InLF and InURB found to be not stationary. In the first differences, all variables on both tests are stationary.

Table 4: First-generation panel unit root tests

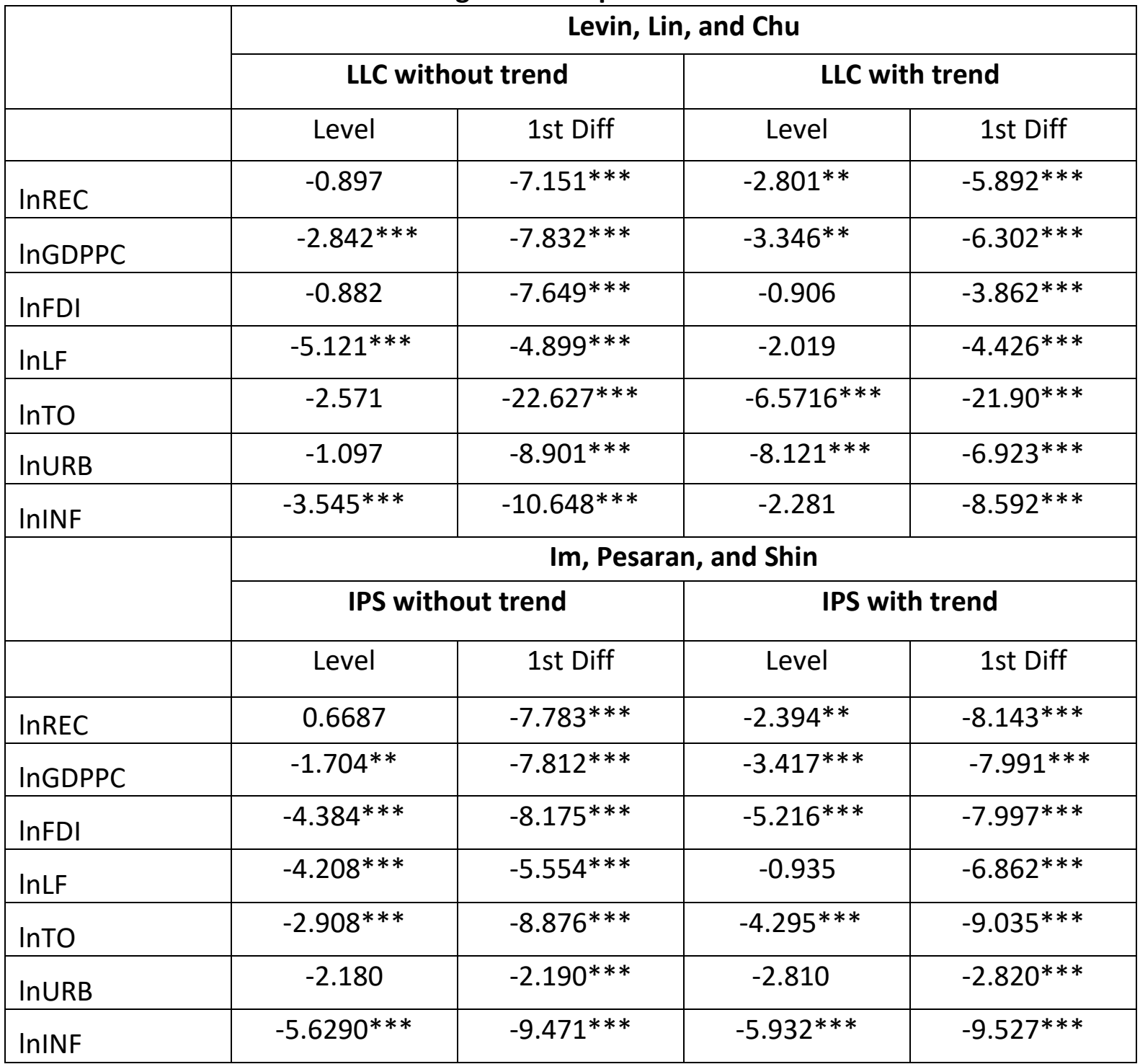

Note: $*, * *, * * *$ indicate statistical significance at $10 \%, 5 \%$ and $1 \%$ level respectively. The null hypothesis is that variable is non-stationary.

Nonetheless, an estimation can produce spurious results if cross-sectional dependence exists across ASEAN countries. Thus, it is essential to test for cross-sectional dependence among ASEAN countries using the Pesaran (2007) CIPS test. The panel unit root test is presented in Table 5. The results revealed that there are mixed results at level, nevertheless become stationary for all series including with trends-stationary process at first different. These results implied that any possible shock affecting the series is only a temporary effect. Hence, we can proceed with the estimations. 
INTERNATIONAL JOURNAL OF ACADEMIC RESEARCH IN BUSINESS AND SOCIAL SCIENCES Vol. 11, No. 1, 2021, E-ISSN: 2222-6990 @ 2021 HRMARS

Table 5: Panel Unit Roots Test based on Pesaran (2007)

\begin{tabular}{|l|c|c|c|c|}
\hline \multirow{2}{*}{} & \multicolumn{4}{|c|}{ CIPS } \\
\cline { 2 - 5 } & \multicolumn{2}{|c|}{ CIPS without trend } & \multicolumn{2}{c|}{ CIPS with trend } \\
\cline { 2 - 5 } & Level & 1 st Diff & Level & 1 st Diff \\
\hline InREC & -1.686 & $-5.187^{* * *}$ & $-3.282^{* * *}$ & $-5.230^{* * *}$ \\
\hline InGDPPC & $-2.456^{* * *}$ & $-4.627^{* * *}$ & $-2.903^{* *}$ & $-4.642^{* * *}$ \\
\hline $\operatorname{InFDI}$ & -3.095 & $-5.187^{* * *}$ & $-3.578^{* * *}$ & $-5.292^{* * *}$ \\
\hline $\operatorname{InLF}$ & -3.538 & $-3.579^{* * *}$ & -1.754 & $-4.856^{* * *}$ \\
\hline InTO & $-2.554^{* * *}$ & $-5.286^{* * *}$ & $-3.191^{* * *}$ & $-5.391^{* * *}$ \\
\hline InURB & $-0.765^{* * *}$ & $-2.838^{* * *}$ & -1.797 & $-3.335^{* * *}$ \\
\hline InINF & -3.305 & $-5.993^{* * *}$ & $-3.826 * * *$ & $-6.035^{* * *}$ \\
\hline
\end{tabular}

Notes: CIPS test developed with the command of xtcips of stata 14 with 3 maximum lags; the critical value for CIPS statistics at $\left({ }^{* * *}\right) 1$ percent, $\left({ }^{* *}\right) 5$ percent, and $\left({ }^{*}\right) 10$ percent level. The null hypothesis is that the variable is homogeneous non-stationary.

Table 6 shows the result of DCCE estimator in analyzing the effects of macroeconomic indicators on renewable energy consumption in ASEAN countries. The coefficient of the lagged renewable energy consumption is significant and positive in all regression. This result justifies the use of a dynamic panel data model in estimating the association between variables. The GDP per capita has a positive relationship with the lagged renewable energy consumption (InREC) where based on the mean group DCCE, a 1 percent increase in GDP per capita (InGDPPC) will cause the renewable energy consumption to increase by 0.155 percent. Economic growth is essential to accelerate the spread of renewable energy consumption as agreed by Lau et al. (2018). An increase in economic growth reflected higher living standards and increasing purchasing powers, thus increase the willingness to invest and switch to renewable energy resources.

In terms of the effect of foreign direct investment (InFDI), the evidence suggests that a 1 percent increase in InFDI, leads to approximately 0.020 percent reduction in InREC mean group DCCE. The trade openness (InTO) exhibit similar sign like InFDI. Statistically, a 1 percent increase in InTO reduces InREC by 0.125 percent. These results show that the foreign investors and trade activities still heavily depended on pollutive types of energy such as coal and fossil fuel as it is relatively cheaper compare to renewable energy.

Next, the result also shows that an increase in the urban population (InURB) can lead to a reduction of InREC. It is demonstrated that 1 percent increase in InURB will decrease the InREC by 2.785 percent. This result contradicts with Kumaran et al. (2020) whereas the growing urban population will required more energy to sustain the rapid population growth. Avtar et al. (2019) stated that the rapid population growth will increase the demand for nonrenewable energy because more affordable and reliability is higher.

Referring to the inflation rate (InINF), DCCE method result suggests that InINF is negatively related to InREC. This indicates that an increase in InINF by 1 percent will reduce the InREC by only 0.010 percent. This clarifies the perspective of households and firms as the rising interest rates diminish the willingness to invest and switch to renewable energy resources as the cost of renewable energy also increases (Schmidt et al., 2019).

Lastly, the Cross-Sectional Dependence (CD) test revealed that the error term is weakly cross-sectional dependence as it does not reject the null hypothesis ( $p$-value>0.005). Meanwhile, the R-square indicates the model explains $0.46-0.49$ percent of the cross-country 
variation. For robust checks, the model again estimates using the Jackknife bias correction and Recursive mean adjustment method and shows that the results of the estimation are stable and corroborate with the main estimations when accounted for small sample time series bias corrections.

Table 6: Result of Heterogeneous Estimation using Dynamic Common Correlated Effects

\begin{tabular}{|c|c|c|c|}
\hline \multicolumn{4}{|c|}{ Dynamic Common Correlated Effects (DCCE) } \\
\hline Variable & $\begin{array}{c}\text { Mean Group } \\
\text { (MG) }\end{array}$ & $\begin{array}{c}\text { Jackknife Bias } \\
\text { Correction }\end{array}$ & $\begin{array}{c}\text { Recursive mean } \\
\text { adjustment }\end{array}$ \\
\hline $\operatorname{lnREC}_{\mathrm{it}-1}$ & $\begin{array}{l}0.350 * * \\
(0.155)\end{array}$ & $\begin{array}{c}0.918 * * \\
(0.360)\end{array}$ & $\begin{array}{r}0.402^{* * *} \\
(0.118)\end{array}$ \\
\hline $\operatorname{lnGDPPC}$ & $\begin{array}{c}0.155^{* *} \\
(0.928)\end{array}$ & $\begin{array}{r}0.475 * * \\
(0.645)\end{array}$ & $\begin{array}{l}0.111^{*} \\
(0.753)\end{array}$ \\
\hline InFDI & $\begin{array}{r}-0.020 * \\
(0.037)\end{array}$ & $\begin{array}{c}-0.090 * \\
(0.089)\end{array}$ & $\begin{array}{r}-0.015^{* *} \\
(0.038)\end{array}$ \\
\hline $\operatorname{lnLF}$ & $\begin{array}{l}0.115 \\
(0.181)\end{array}$ & $\begin{array}{c}1.193 \\
(0.878)\end{array}$ & $\begin{array}{l}0.348^{*} \\
(0.205)\end{array}$ \\
\hline InTO & $\begin{array}{c}-0.125 * * \\
(0.065)\end{array}$ & $\begin{array}{c}-0.120 * \\
(0.079)\end{array}$ & $\begin{array}{r}-0.061 * * \\
(0.033)\end{array}$ \\
\hline InURB & $\begin{array}{r}-2.785^{* *} \\
(2.555)\end{array}$ & $\begin{array}{r}-8.245^{*} \\
(8.388)\end{array}$ & $\begin{array}{r}-3.742 * \\
(3.736)\end{array}$ \\
\hline InINF & $\begin{array}{r}-0.010 * \\
(0.011)\end{array}$ & $\begin{array}{c}-0.110 * \\
(0.070)\end{array}$ & $\begin{array}{l}0.001 \\
(0.013)\end{array}$ \\
\hline Constant & $\begin{array}{c}78.23^{* *} \\
(10.80)\end{array}$ & $\begin{array}{c}14.676^{* * *} \\
(10.65)\end{array}$ & $\begin{array}{c}29.352 * * * \\
(16.07)\end{array}$ \\
\hline Obs. & 233 & 233 & 233 \\
\hline R-squared & 0.46 & 0.49 & 0.49 \\
\hline $\begin{array}{c}\text { CD Statistic } \\
\text { (p-value) }\end{array}$ & $\begin{array}{l}-1.64 \\
(0.102)\end{array}$ & $\begin{array}{c}-0.50 \\
(0.615)\end{array}$ & $\begin{array}{c}-1.36 \\
(0.1746)\end{array}$ \\
\hline
\end{tabular}

Note: All variables are expressed $\left({ }^{*}\right)$ significant at the 10 percent level, $\left({ }^{* *}\right)$ significant at 5 percent level, and $\left({ }^{* *}\right)$ significant at the 1 percent level. The analysis uses dynamic common correlated effects estimation developed by Chudik and Pesaran (2015). Figure in parentheses are standard error, Cross-Sectional Dependence (CD) test which is p-value and the null hypothesis is that the error terms are weakly cross-sectional dependent

\section{Conclusion and Recommendation}

This paper investigates empirically the macroeconomics factors in influencing the renewable for ASEAN countries during the period 1990-2015. To our knowledge, the nexus between macroeconomics factors and renewable energy consumption has not been beforehand analyzed using the Dynamic Common Correlated Estimators (DCCE). It is, therefore, providing 
a more different perspective by considering the presence of country-specific effect as well as the common shocks and interdependencies exists among ASEAN countries

Based on the finding discussed in the previous section, several recommendations were identified through this study. Firstly, it is important to effectively tackle the renewable energy cost problem, to provide affordable and reliable renewable energy, and at the same time strategy to safeguard against a rising interest rate. The price of renewable energy has not been competitive because of the existence of subsidies for fuel oil and electricity which generally cheaper. Based on the present results, an increase in the cost of living can reduce the demand for renewable energy.

Secondly, the monetary cost associated with diseconomies of agglomeration in an urban area will discourage investment in renewable energy sources as fossil-fuel-based energy costs are lower compare to renewable energy sources. Thus, proper strategy and initiative to contain the costs of agglomeration by considering; 1 ) Incorporating technology in urban services to promote smart cities and efficient transport and traffic system, 2) Decentralizing urban areas associated with decentralized energy supply to set-up renewable energy supply in certain urban areas.

Next, the accumulation of labor force participation produces individual income growth. Human resource is directly associated with economic growth which further influences positively the renewable energy consumption. Further effort is required to empowering the quality of skilled workers particularly in the applications of green skills that are necessary for sustainable development since renewable technology are required HighTech imputes and technical expertise.

Lastly, a higher degree of trade openness and FDI in ASEAN countries reducing the demand for renewable energy. Therefore, it is essential to start the initiatives to attract foreign investors in the renewable energy sector and promotes green technology transfer through trade openness. This can be done by adopting fiscal instruments such including incentives for the low-carbon sector, facilitating market access and enlarging markets of the renewable energy sector, and establish platforms and facilities that green technologyfriendly.

\section{Corresponding Author}

Jain Yassin

Faculty Business and Management, Universiti Teknologi MARA (UiTM), Kota Kinabalu, Sabah Malaysia.

Email: jainyassin@uitm.edu.my

\section{References}

ADB. (2015). Renewable Energy Developments and Potential in The Greater Mekong Subregion. In Statewide Agricultural Land Use Baseline 2015. Retrieved on https://doi.org/10.1017/СВ09781107415324.004

IRENA. (2018). Renewable Power Generation Costs in 2018. In International Renewable Energy Agency. https://doi.org/10.1007/SpringerReference_7300

Akar, B. G. (2016). The Determinants Of Renewable Energy Consumption: An Empirical Analysis For The Balkans. An empirical analysis for The Balkans. European Scientific Journal, 12(11). https://doi.org/10.19044/esj.2016.v12n11p594

ADBI. (2016). In ASEAN 2030: Toward a Borderless Economic Community.

Avtar, R., Tripathi, S., Aggarwal, A. K., \& Kumar, P. (2019). Population-Urbanization-Energy 
Nexus: A Review. Resources, 8(3), 136. https://doi.org/doi:10.3390/resources8030136 Bilgili, F., \& Ozturk, I. (2015). Biomass energy and economic growth nexus in G7 countries: Evidence from dynamic panel data. Renewable and Sustainable Energy Reviews, 49, 132138. https://doi.org/10.1016/j.rser.2015.04.098

Cadoret, I., \& Padovano, F. (2016). The political drivers of renewable energies policies. Energy Economics, 56, 261-269. https://doi.org/10.1016/j.eneco.2016.03.003

Chen, Y. (2018). Factors influencing renewable energy consumption in China: An empirical analysis based on provincial panel data. J Journal of Cleaner Production, 174, 605-615.

Chudik, A., \& Pesaran, M. H. (2015). Common correlated effects estimation of heterogeneous dynamic panel data models with weakly exogenous regressors. Journal of Econometrics, 188(2), 393-420. https://doi.org/10.1016/j.jeconom.2015.03.007

Ergun, S. J., Owusu, P. A., \& Rivas, M. F. (2019). Determinants of renewable energy consumption in Africa. Environmental Science and Pollution Research, 26(15), 1539015405. https://doi.org/10.1007/s11356-019-04567-7

Frondel, M., Ritter, N., Schmidt, C. M., \& Vance, C. (2010). Economic impacts from the promotion of renewable energy technologies: The German experience. Energy Policy, 38(8), 4048-4056. https://doi.org/10.1016/j.enpol.2010.03.029

Hassine, M. Ben, \& Harrathi, N. (2017). The causal links between economic growth, renewable energy, financial development and foreign trade in gulf cooperation council countries. International Journal of Energy Economics and Policy, 7(2), 76-85.

Heng, P. (2018). Toward a low carbon energy transition in Cambodia. Retrived on https://www.kas.de/documents/265079/265128/Toward+a+low+carbon+energy+trans ition+in+Cambodia+\%28June+1\%29.pdf/32c1309b-e589-edc4-bc6d4d268428f4e7?version $=1.0 \& \mathrm{t}=1554886064066$

Hoechle, D. (2007). Robust standard errors for panel regressions with cross-sectional dependence.The stata journal, 7(3), 281-312.

Im, K. S., Pesaran, M. H., \& Shin, Y. (2003). Testing for unit roots in heterogeneous panels. Journal of econometrics, 115(1), 53-74. https://doi.org/10.1016/S0304-4076(03)000927

IRENA. (2019). Renewable Energy Statistics 2019. In International Renewable Energy Agency. Kumaran, V. V., Ridzuan, A. R., Khan, F. U., Abdullah, H., \& Mohamad, Z. Z. (2020). An empirical analysis of factors affecting renewable energy consumption in association of Southeast Asian nations-4 countries. International Journal of Energy Economics and Policy, 10(2), 48-56. https://doi.org/10.32479/ijeep.8142

Lau, L. S., Yii, K. J., Lee, C. Y., Chong, Y. L., \& Lee, E. H. (2018). Investigating the determinants of renewable energy consumption in Malaysia: An ARDL approach. International Journal of Business \& Society, 19(3).

Levin, A., Lin, C. F., \& Chu, C. S. J. (2002). Unit root tests in panel data: Asymptotic and finitesample properties. Journal of econometrics, 108(1), 1-24. https://doi.org/10.1016/S0304-4076(01)00098-7

Lin, B., Omoju, O. E., \& Okonkwo, J. U. (2016). Factors influencing renewable electricity consumption in China. Renewable and Sustainable Energy Reviews, 55, 687-696. https://doi.org/10.1016/j.rser.2015.11.003

Malik, I. A., Siyal, G. E. A., Bin Abdullah, A., Alam, A., Zaman, K., Kyophilavong, P., Shahbaz, M., Baloch, S. U., \& Shams, T. (2014). Turn on the lights: Macroeconomic factors affecting renewable energy in Pakistan. Renewable and Sustainable Energy Reviews, 38, 277-284. https://doi.org/10.1016/j.rser.2014.05.090 
Omri, A., \& Nguyen, D. K. (2014). On the determinants of renewable energy consumption: International evidence. Energy, 72, 554-560. https://doi.org/10.1016/j.energy.2014.05.081

Pesaran, M. H. (2007). A simple panel unit root test in the presence of cross-section dependence. Journal of applied econometrics, 22(2), 265-312. https://doi.org/10.1002/jae.951

Pesaran, M. H., Pesaran, M. H., Shin, Y., \& Smith, R. P. (1999). Pooled Mean Group Estimation of Dynamic Heterogeneous Panels. Journal of the American statistical Association, 94(446), 621-634. https://doi.org/10.1080/01621459.1999.10474156

Pillai, G. M. (2014). Lao PDR National Sustainable Energy Strategy Report: Enabling Environment and Technology Innovation Ecosystem for Affordable Sustainable Energy Options. Retrieved onhttps://www.unescap.org/sites/default/files/Lao\%20PDR\%20National\%20Sustainabl e\%20Energy\%20Strategy\%20Report.PDF

Rosellon, M. A. D. (2017). The renewable energy policy debate in the Philippines. Philippines Institute for Development Studies, 17(April), 1-43.

Schmidt, T. S., Steffen, B., Egli, F., Pahle, M., Tietjen, O., \& Edenhofer, O. (2019). Adverse effects of rising interest rates on sustainable energy transitions. Nature Sustainability, 2(9), 879-885. https://doi.org/10.1038/s41893-019-0375-2

Singh, N., Nyuur, R., \& Richmond, B. (2019). Renewable energy development as a driver of economic growth: Evidence from multivariate panel data analysis. Sustainability, 11(8), 2418. https://doi.org/10.3390/su11082418

Yassin, J., \& Aralas, S. B. (2019). Economic Structural Transformation and CO2 Emissions in Asian Countries: Homogeneous Vs. Heterogeneous Estimators. Journal of Tourism, Hospitality and Environment Management, 4(13), 57-68. https://doi.org/10.2139/ssrn.3398375

Zhao, P., Lu, Z., Fang, J., Paramati, S. R., \& Jiang, K. (2020). Determinants of renewable and non-renewable energy demand in China. Structural Change and Economic Dynamics, 54, 202-209

Zhao, X., \& Luo, D. (2017). Driving force of rising renewable energy in China: Environment, regulation and employment. Renewable and Sustainable Energy Reviews, 68, 48-56. https://doi.org/10.1016/j.rser.2016.09.126

World Bank. (2020). World Development Indicators. Retrieve on https://data.worldbank.org/indicator. 